\title{
miRNA-489 as a biomarker in diagnosis and treatment of cervical cancer
}

\author{
Juan $\mathrm{C}^{1}$, Hua $\mathrm{Q}^{2}$, Ruping $\mathrm{Z}^{2}$, Tingting $\mathrm{W}^{1}$ \\ Taizhou Polytechnic College, Taizhou City, Jiangsu Province, China. chenjuan2017@sina.com
}

\begin{abstract}
miRNA-489 was shown to be a suppressor factor in many cancers, however, evidence on the effects and mechanism of miRNA-489 in progression of cervical cancer is limited. So we aimed to determine the function of miRNA-489 in cervical cancer proliferation and apoptosis in our present study. Interestingly, we found that miRNA-489 was significantly down-regulated in cervical cancer tissues. miRNA-489 overexpression inhibited the cell proliferation and improved the cell apoptosis of cervical cancer cells. Further, miRNA-489 over-expression suppressed the activation of PI3K and AKT, and stimulated P53 proteins expression. In conclusion, our results suggested that miRNA-489 may be considered as a biomarker in cervical cancer and had suppressed the cell proliferation and stimulated cell apoptosis via PI3K/AKT/P53 signaling pathway (Fig. 5, Ref. 26). Text in PDF www.elis.sk.

KEY WORDS: miRNA-489, PI3K, AKT, P53, biomarker.
\end{abstract}

\section{Introduction}

Cervical cancer is one of the most common gynecologic malignancies, with approximately 500 thousand new cases worldwide and about 300 thousand deaths each year. In recent years, related reports had shown that the incidence of cervical cancer is moving to younger age. Cervical cancer is known to be associated with high-risk HPV infection. However, studies have found that single high-risk HPV infection is not enough to cause cervical cancer, genetic factors and immune factors also play an important role in the development of cervical cancer (1-3). The study of the mechanism of cervical cancer development and diagnosis and treatment of cervical cancer is the focus of medical research.

The discovery of miRNAs offers hope for treatment of cervical cancer patients. The relative studies found that the abnormal expression of miRNAs is closely related to the occurrence and development of most tumors (4-6). MiRNA-489 is lowly expressed in many tumors such as melanoma, breast cancer and prostate cancer, suggesting that miR-489 is a tumor related factor (7-9). Up-regulation of miRNA-489 interferes with growth factor signaling pathway and promotes cell proliferation $(10,11)$. However, reports on the correlation between miRNA-489 and cervical cancer are limited. In our present study, we firstly evaluated the miR-489 expression in cervical cancer and adjacent normal tissues, secondly, we studied the effects and mechanism of miRNA-489

${ }^{1}$ Taizhou Polytechnic College, Taizhou City, Jiangsu Province, China, and ${ }^{2}$ Taizhou People's Hospital, Taizhou City, Jiangsu Province, China

Address for correspondence: C, Juan, Taizhou Polytechnic College, No. 8 Tianxing Road, High-tech Medical Park District, Taizhou City 225300, Jiangsu Province, China over-expression in cell proliferation and apoptosis of cervical cancer cells in in vitro study.

\section{Materials and methods}

\section{Clinical data}

20 pairs of tumor and adjacent normal tissues from cervical cancer patients who were admitted to Taizhou People's Hospital from 2015 to 2016 were collected. The tissues were fixed in the 4 $\%$ faure Marin solution for $48 \mathrm{~h}$, after that the tissues were stained with $\mathrm{H} \& \mathrm{E}$ and were subjected to in situ hybridization (ISH).

\section{H\&E staining}

After routine dehydration, soaking wax, embedding, slicing, xylene dewaxing and hydration, hematoxylin staining was performed. The alcohol was added to $0.5 \%$ hydrochloric acid and stained with $0.5 \%$ eosin solution; dehydrated after neutral balata. The samples were observed under an optical microscope.

\section{ISH methods}

After routine dehydration, soaking wax, embedding, slicing, glass cleaning, baking $7 \mathrm{~h}$ at $180^{\circ} \mathrm{C}$, and use the sterilized cotton swab on the slide under aseptic condition. After the drying, the dust is dust-free and the package is kept at $4{ }^{\circ} \mathrm{C}$. Paraffin section at $60{ }^{\circ} \mathrm{C}$ of rewarming, routine dewaxing, rehydration; $3 \% \mathrm{H}_{2} \mathrm{O}_{2}$ at room temperature, $10 \mathrm{~min}$, DEPC treated distilled water washing 3 times, each time $5 \mathrm{~min} ; 3 \%$ citric acid diluted pepsin, $37^{\circ} \mathrm{C}$ 20 min digestion. $80 \mathrm{~mL}$ pre-hybridization droplets were added to the slides, and $20 \mathrm{ml} 20 \%$ glycerin was placed in the wet box to keep the moisture content in the box, and the temperature was raised at $37^{\circ} \mathrm{C}$ for $4 \mathrm{~h}$. Then $90 \mathrm{ml}$ hybrid solution was added to 
A
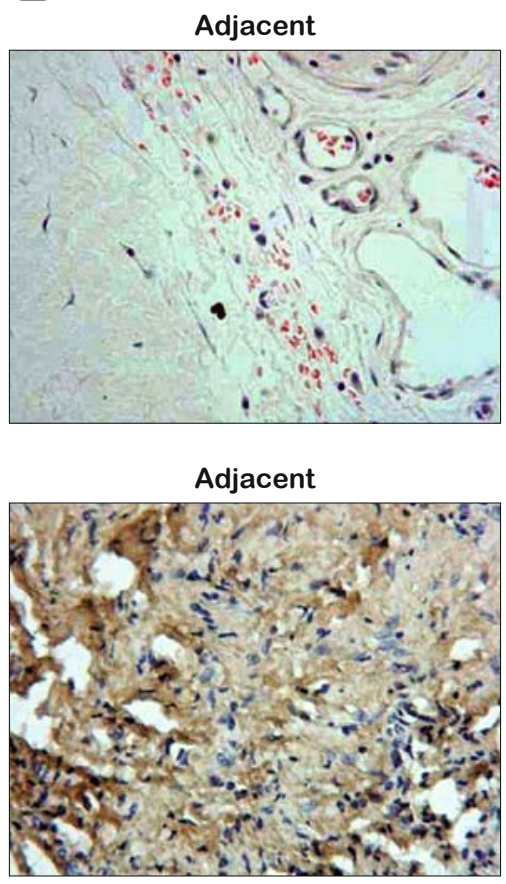

Cancer

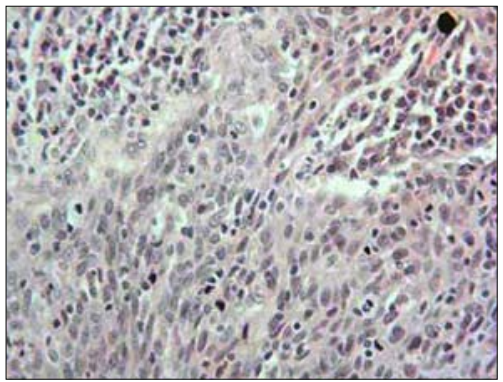

Cancer

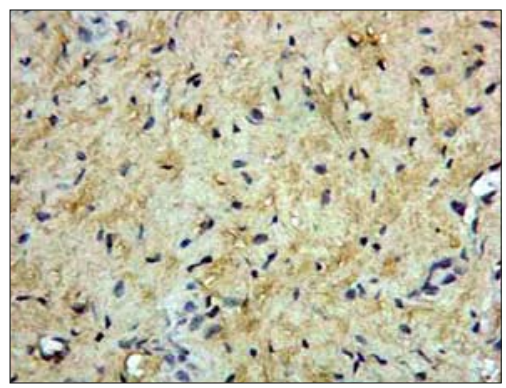

B

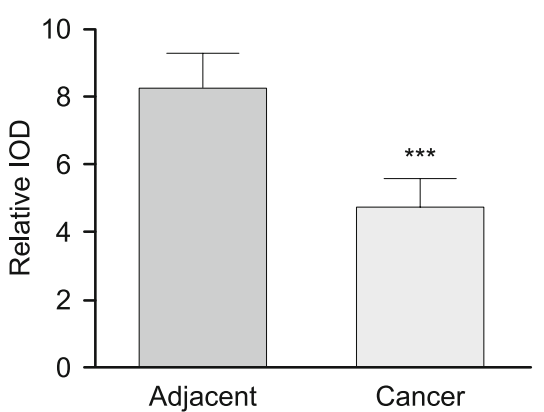

Fig. 1. The clinical data in cervical cancer. 1A: The pathology of cervical and adjacent normal tissues by H\&E staining ('200). 1B. The miRNA-489 expression in cervical and adjacent normal tissues by ISH ('200). ${ }^{* * *} \mathrm{p}<0.05$, compared with NC group.
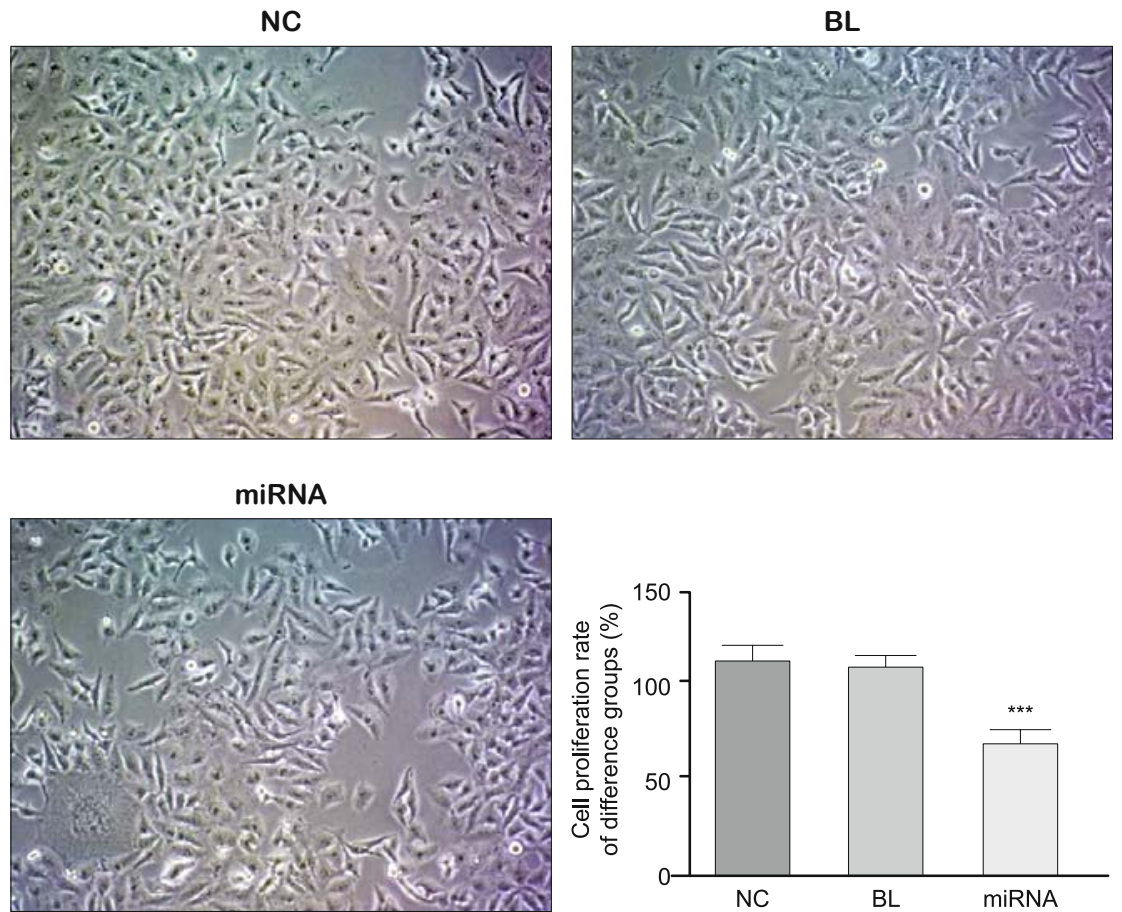

Fig. 2. The cell proliferation of different groups. ${ }^{* * *} \mathrm{p}<0.05$, compared with NC group.

every section, cultured at $42{ }^{\circ} \mathrm{C} \sim 45^{\circ} \mathrm{C}$ for $16 \sim 20 \mathrm{~h}$. Then it was washed by preheat $2 \times \mathrm{SSC}, 0.5 \times \mathrm{SSC}$ and $0.2 \times \mathrm{SSC}$ at $37^{\circ} \mathrm{C}, 3$ times for $5 \mathrm{~min}$. Drip sealing solution, $37^{\circ} \mathrm{C}$ for $30 \mathrm{~min}$, Throw out the excess liquid; Biotinylated Rabbit anti digoxin, cultured at $37^{\circ} \mathrm{C}$ for $60 \mathrm{~min}$; After washing by PBS, adding the SABC to culture at $37^{\circ} \mathrm{C}$ for $20 \mathrm{~min}$; Washing by PBS and coloring by DAB, He- 
NC
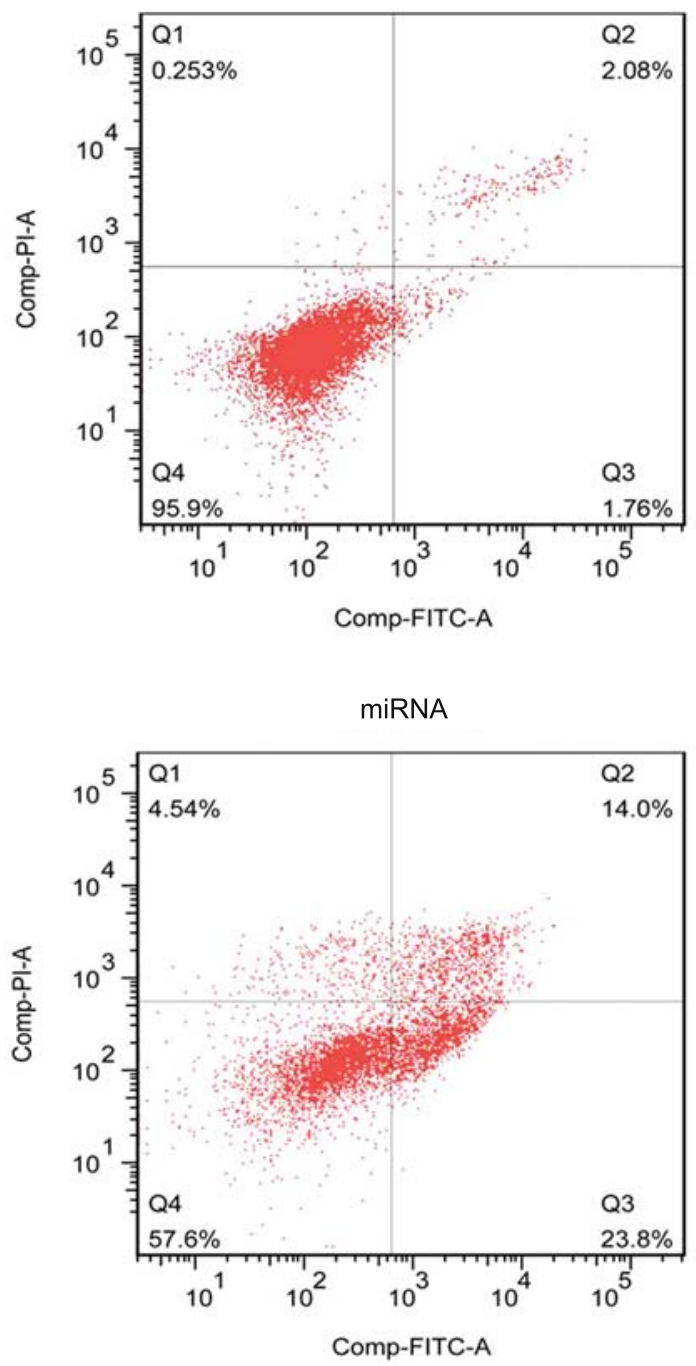

$\mathrm{BL}$
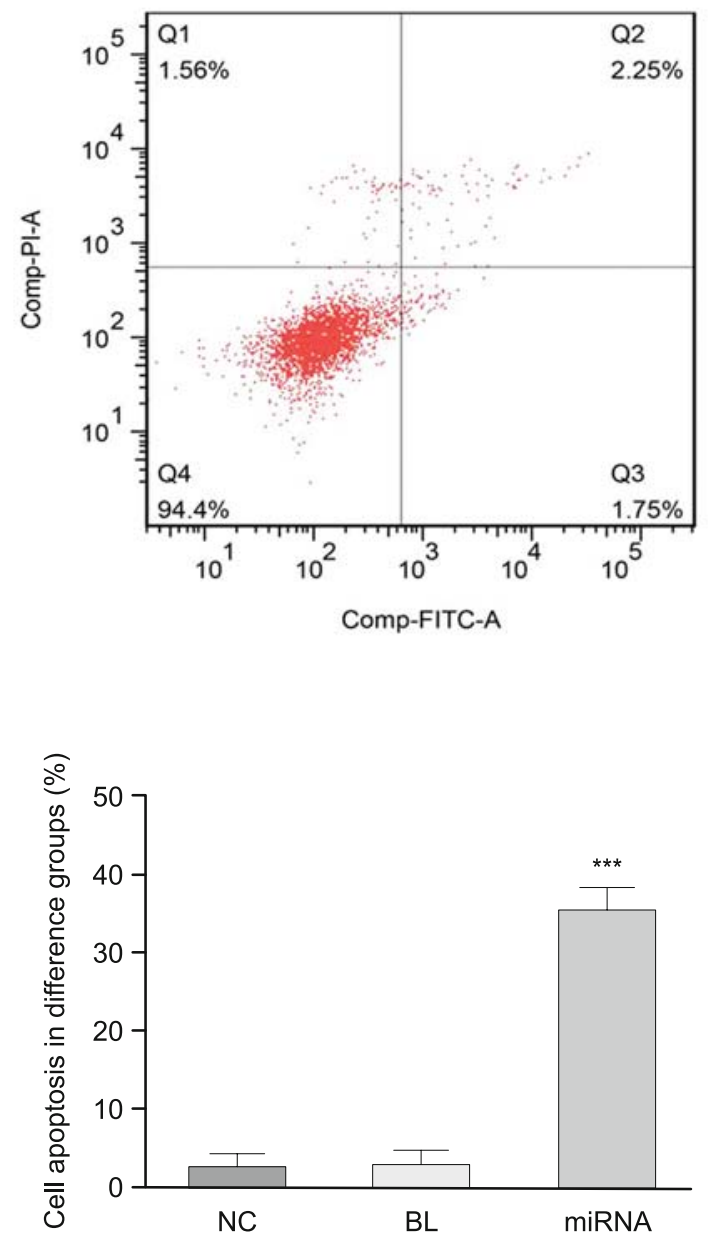

Fig. 3. The cell apoptosis of different groups. ${ }^{* * *} \mathbf{p}<\mathbf{0 . 0 5}$, compared with NC group.

matoxylin staining, washed back to blue, dehydrated, transparent, neutral balata, observation under the microscope.

\section{Cell culture and grouping}

Hela cells which have been purchased from ATCC (USA) were cultured in RPMI 1640 culture medium containing $10 \%$ fetal bovine serum, $100 \mathrm{U} / \mathrm{ml}$ Streptomycin and $300 \mathrm{mg} / \mathrm{L}$ glutamine and conventional subculture. The Hela were divided into 3 groups: NC group (treated with normal treatment); BL group (transfected with empty vector) and miRNA group (transfected with miRNA-489).

\section{Cell transfection}

The Hela cells in logarithmic growth phase were inoculated to the 6 pore plate at $4 \times 10^{6}$ cells/ pore, and each cell $2 \mathrm{ml}$ was divided into 3 groups after cell adherence: (1) NC group: the cells were treated with normal treatment; (2) BL group: the cells were transfected with $50 \mathrm{nmol} / \mathrm{L}$ Lipofectamine 2000; (3) miRNA group: the cells were transfected with $50 \mathrm{nmol} / \mathrm{L}$ Lipofectamine 2000 with miRNA-489.

\section{Cell proliferation by CCK-8}

The transfected Hela cells resulted in single cell suspension after $24 \mathrm{~h}$, and $4 \times 10^{3}$ cells per hole were injected into the 96 hole plate, each hole $200 \mathrm{~mL}$, After cell attachment, it was cultured in the incubator for $48 \mathrm{~h}, 5$ holes were set in each group, and a blank correction group (without adding PBS of the same amount of cells) was set up. At the end of culturing for $1 \mathrm{~h}, 0.01 \mathrm{ml} \mathrm{CCK}-$ 8 solution was added to each pore. Then the cells were cultured for $1 \mathrm{~h}$, the cell proliferation was measured by enzyme labelling apparatus at $490 \mathrm{~nm}$.

\section{Cell apoptosis by flow cytometry}

Collecting the cells of different groups which were cultured for $24 \mathrm{~h}$ it was Operated in accordance with the apoptosis of An- 
NC
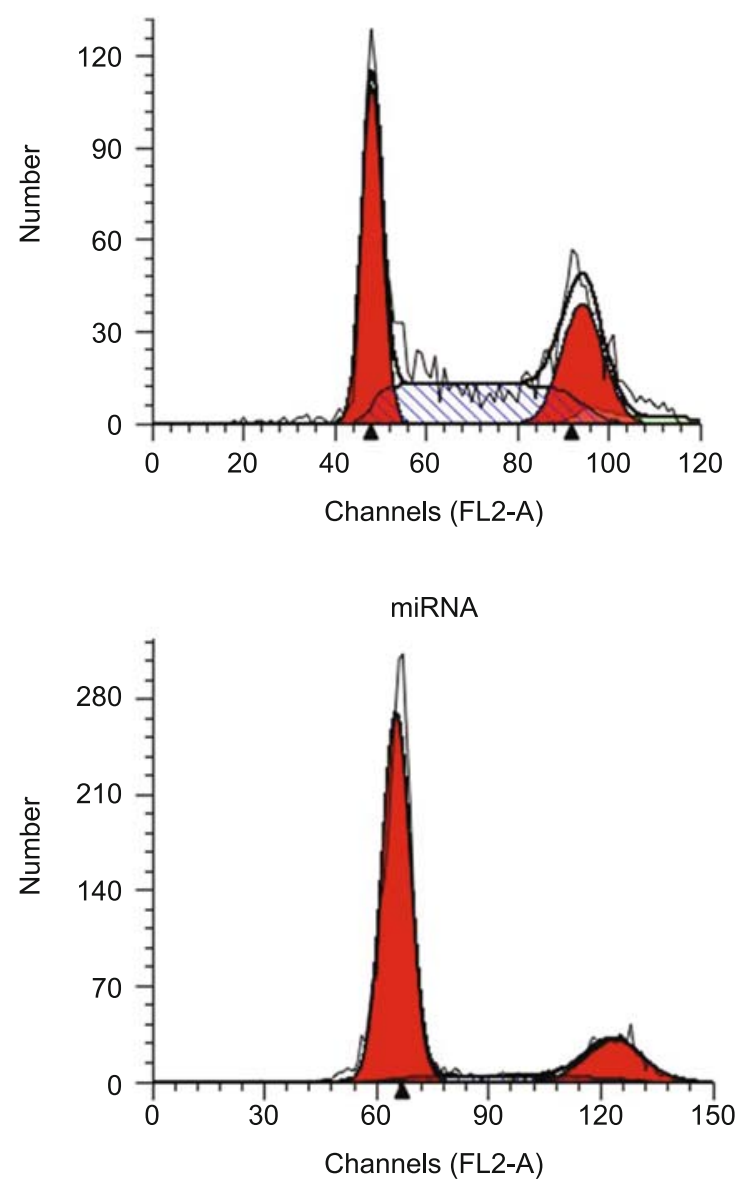

$B L$
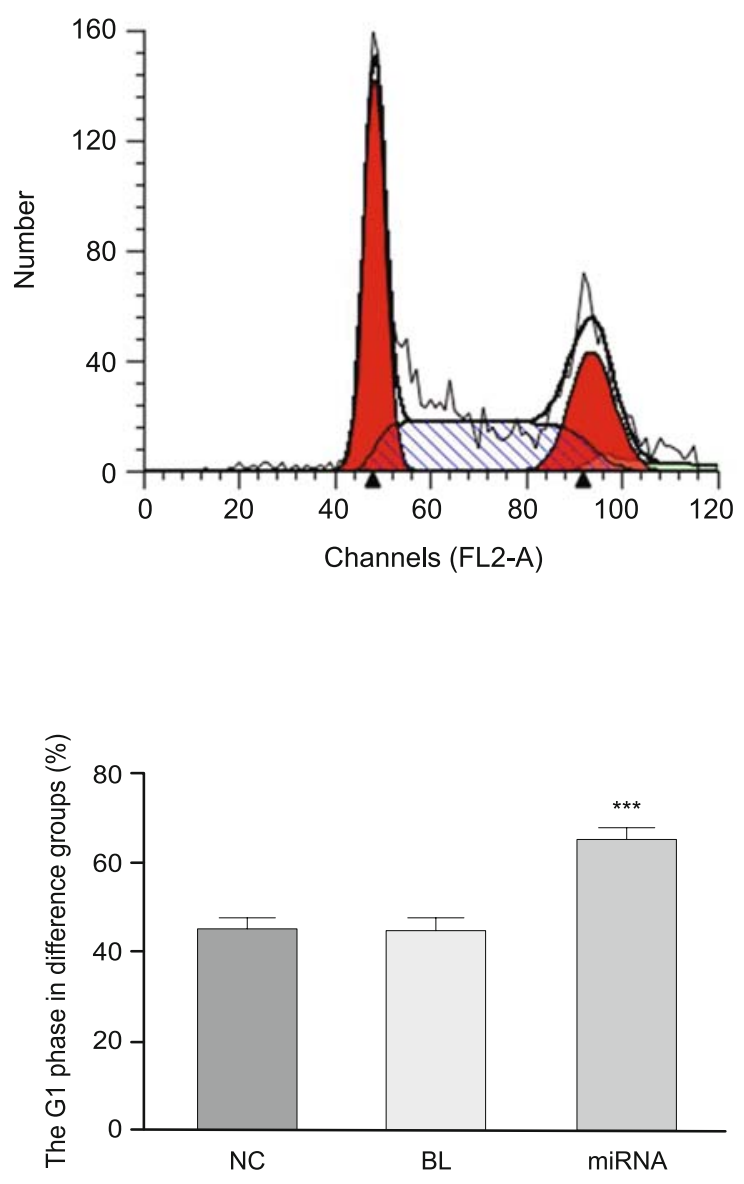

Fig. 4. The cell cycle of different group. ${ }^{* * *} \mathrm{p}<0.05$, compared with NC group.

nexin V-FITC cells detection kit, to join the $5 \mu$ LAnnexin V-FITC after mixing, adding $5 \mu \mathrm{L}$ propidium iodide (PI), light reaction at room temperature for $15 \mathrm{~min}$ and immediate detection by flow cytometry.

\section{Cell cycle by flow cytometry}

The cells of different groups were collected and were prepared into single cell suspensions and operated according to the cell cycle test kit instructions. After washing the cells with PBS to join the $10 \mathrm{~g} / \mathrm{ml}$ DNaseA, 37 DEG $30 \mathrm{~min}$, adding $10 \mathrm{~g} / \mathrm{ml} \mathrm{PI}$ at room temperature and light reaction of $30 \mathrm{~min}$, flow cytometry was performed after using Modifit software to analyze the distribution of cell cycle in each group.

\section{WB assay}

Collecting the Hela cells of different groups, Cell lysis and separation of cell protein samples by measuring the amounts of protein Bradford concentration ( $20 \mathrm{~g} /$ hole), conventional $8 \%$ SDS-PAGE electrophoresis, semi dry transfer membrane transfer membrane, $5 \%$ skim milk powder closed, with specific antibody (1:1000) to
$4{ }^{\circ} \mathrm{C}$ overnight incubation, HRP labeled Goat anti rabbit IgG as second antibody $(1: 2500)$ and incubated at room temperature for $1 \mathrm{~h}$, ECL color, strip exposure intensity with Quantity (Bio, RAD) One 4.6.2 analysis software, using GAPDH as internal control, and internal control through the gray ratio, the relative expression amount of the target band.

\section{Statistical analysis and methods}

The data were analyzed by SPSS 20.0 software, measurements are expressed as mean \pm standard deviation, variance analysis was used between the normal distribution variables and the multiple groups, and the $\mathrm{t}$ test was used between the two groups, $\mathrm{p}<0.05$ showed significant statistical difference.

\section{Results}

\section{Clinical and analyzing}

By the H\&E staining, the invasion and migration of cancer tissues were significantly enhanced compared with adjacent normal tissues (Fig. 1A). The miRNA-489 expression of cervical cancer 

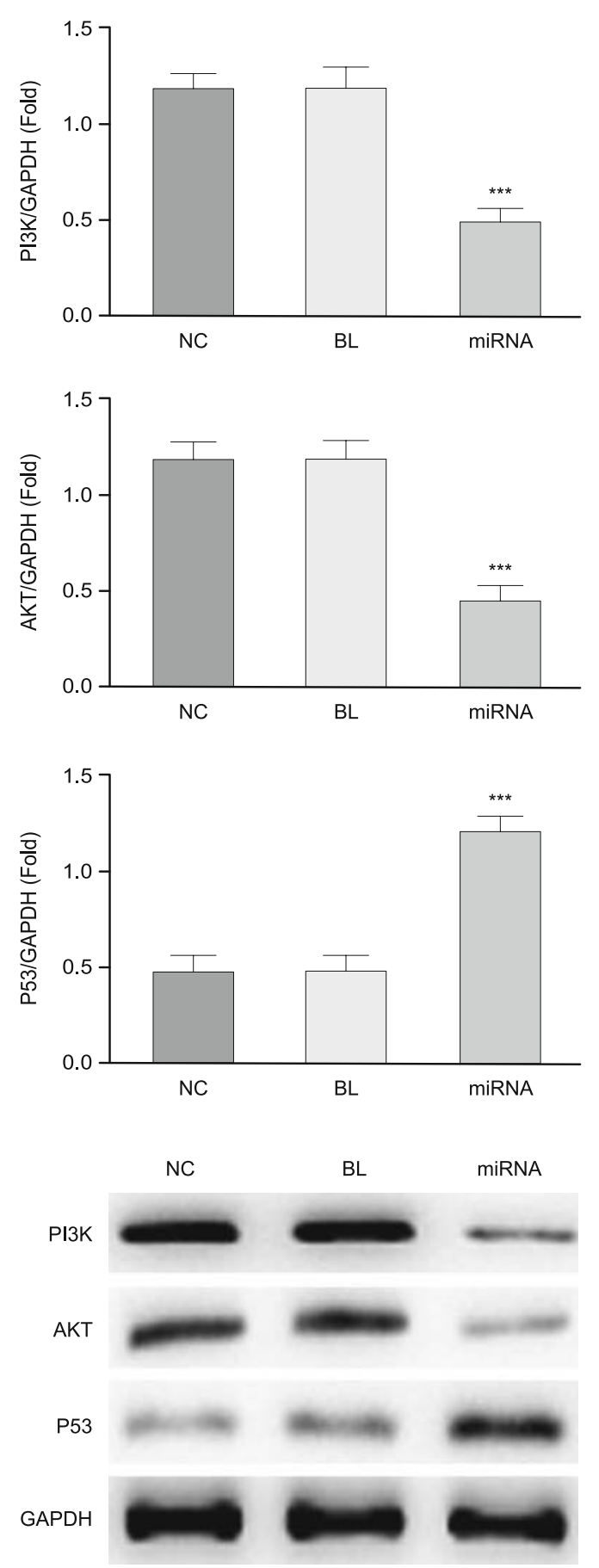

Fig. 5. The relative proteins expressions of different groups. $* * * \mathbf{p}<$ 0.05, compared with NC group.

tissues were significantly down-regulated compared with adjacent normal tissues $(p<0.05)$ (Fig. 1B).

\section{Cell proliferation by CCK-8 assay}

Compared with NC group, the cell proliferation rate of miRNA group was significantly suppressed $(\mathrm{p}<0.05)$ (Fig. 2).
Cell apoptosis by flow cytometry

To evaluate the effects of miRNA-489 in Hela cells, the cell apoptosis rate of miRNA group was significantly up-regulated compared with NC group $(\mathrm{p}<0.05)$ (Fig. 3).

\section{Cell cycle by flow cytometry}

To measure the effects of miRNA-489 in cell cycle of Hela cells, the G1 phase rate of miRNA group was significantly upregulated compared with NC group $(\mathrm{p}<0.05)$ (Fig. 4).

\section{Relative proteins expressions by WB assay}

Compared with NC group, the PI3K and AKT proteins expressions of miRNA group were significantly suppressed, however, the P53 protein expression of miRNA group was significantly stimulated $(\mathrm{p}<0.05)$ (Fig. 5).

\section{Discussion}

In recent years, the relationship between miRNAs and human tumors has attracted wide attention. The research showed that the expression level of mRNA changed in many cancers, such as lung cancer, colon cancer, miRNA and Burkitt's lymphoma and chronic lymphocytic leukaemia, proto oncogenes and tumor suppressor genes may play a role (12-14). It has been found that miR-21, miR-191, miR-223, miR-let-7a and miR-106b were closely related to the development of cancer (15-18). Studies have shown that miRNA-489 is also associated with the occurrence and development of tumors (8-11). The results of our present study have shown that the expression miRNA-489 was down-regulated in the cervical cancer tissues, the Hela cells proliferation was suppressed and Hela cells apoptosis was improved with miRNA-489 over-expression. PI3K/AKT signaling pathway is an important signal transduction pathway in cells, through the activation of downstream mTOR, NF- kappa B pathway, induced inactivation of Caspase, cyclin related gene transcription or its transcriptional regulator of the formation and regulation of Bcl-2 family members Bcl-2, Bax and Bcl-XL etc. The balance of expression on cell proliferation and apoptosis play an important biological function of resistance (19-22). P53 protein is an important downstream site of PI3K/AKT signaling pathway $(23,24)$. P53 can affect cell proliferation and apoptosis by regulating cell division cycle $(25,26)$. In our present study, with miRNA-489 over-expression, the cell proliferation of Hela cells was significantly suppressed, the cell apoptosis was significantly improved through $\mathrm{G} 1$ phase rate increase $\mathrm{n}$ via regulation of $\mathrm{PI} 3 \mathrm{~K} / \mathrm{AKT} / \mathrm{P} 53$ pathway.

In conclusion, miRNA-489 might be a biomarker and was a suppressor factor in the cervical cancer. With miRNA-489 overexpression, the cell proliferation was suppressed and apoptosis was enhanced by G1 phase rate increase in Hela cells.

\section{References}

1. Torre LA, Bray F, Siegel RL et al. Global cancer statistics 2012. CA Cancer J Clin 2015; 65 (2): 87-108. 
2. Ferlay J, Shin HR, Bray F et al. Estimates of worldwide burden of cancer in 2008: GLOBOCAN 2008. Int J Cancer 2011; 127 (12): 2893-2917.

3. Suprasert P, Charoenkwan K, Siriaree S et al. Outcome of cervical cancer patients with single-node compared with nonodal involvement treated with radical hysterectomy and pelvic lymphadenectomy. Int J Gynaecol Obstet 2013; 121 (1): 45-48.

4. Rogers L, Siu SS, Luesley D et al. Radiotherapy and chemoradiotion after surgery for early cervical. Cochrane Database Syst Rev 20122012 (5): CD007583.

5. Li Z, Lei H, Luo M et al. DNA methylation downregulated mir-10b acts as a tumor suppressor in gastric cancer. Gastric Cancer 2015; 18 (1): 43-54.

6. miR-205 down-regulation promotes proliferation of dermatofibrosarcoma protuberanstumor cells by regulating LRP-1 and ERK phosphorylation. Arch Dematol Res 2014; 306 (4): 367-374.

7. Li J, Qu W, Jiang Y et al. miR-489 Suppresses Proliferation and Invasion of Human Bladder Cancer Cells. Oncol Res 2016; 24 (6): 391-398.

8. Zhang B, Ji S, Ma F et al. miR-489 acts as a tumor suppressor in human gastric cancer by targeting PROX1. Am J Cancer Res 2016; 6 (9): 2021-2030

9. Xie Z, Cai L, Li R et al. Down-regulation of miR-489 contributes into NSCLC cell invasion through targeting SUZ12. Tumour Biol 2015; 36 (8): 6497-6505.

10. Jiang L, He D, Yang D et al. MiR-489 regulates chemoresistance in breast cancer via epithelial mesenchymal transition pathway. FEBS Lett 2014; 588 (11): 2009-2015.

11. Wu H, Xiao Z, Zhang $\mathbf{H}$ et al. MiR-489 modulates cisplatin resistance in human ovarian cancer cells by targeting Akt3. Anticancer Drugs 2014; 25 (7): 799-809.

12. Cimmino A, Calin GA, Fabbri M et al. miR-15 and miR-16 induce apoptosis by targeting Bcl-2. Proc Natl Acad Sci USA 2005; 102 (39): 13944-13949.

13. Yoon C, Kim J, Park G et al. Delivery of miR-155 to retinal pigment epithelial cells mediated byBurkitt's lymphoma exosomes. Tumour Biol 2016; 37 (1): 313-321.

14. Eis PS, Tam W, Sun L, Chadburn A et al. Accumulation of miR155 and BIC RNA in human B cell lymphomas. Proc Natl Acad Sci USA 2005; 102 (10): 3627-3632.

15. Chan SH, Wu CW, Li AF et al. miR-21 microRNA expression in human gastric cancinomas and its clinical association. Anticancer Res 2008; 28 (2A): 907-911.
16. Kim DN, Chae HS, Oh ST et al. Expression of viral microRNAs in Epstein-Barrvirus-associated gastric cancinoma. J Virol 2007; 81 (2): 1033-1036.

17. Xu Q, Dong Q, He C et al. A new polymorphism biomarker rs629367 associated with increased risk and poor survival of gastric cancer in chinese by up-regulated miRNA-let-7a expression. PLoS One 2014; 9 (4): e95249.

18. Luo J, Chen P, Xie W et al. MicroRNA-138 inhibits cell proliferation in hepatocellular carcinoma by targeting Sirt1. Oncol Rep 2017; Jul 3. doi: 10.3892/or.2017.5782. (Epub ahead of print)

19. Yu W, Sun H, Zha W et al. Apigenin Attenuates Adriamycin-Induced Cardiomyocyte Apoptosis via the PI3K/AKT/mTOR Pathway. Evid Based Complement Alternal Med 2017 2017:2590676.

20. Kim SH, Son KM, Kim KY et al. Deoxypodophyllotoxin induces cytoprotective autophagy againstapoptosis via inhibition of PI3K/AKT/ mTOR pathway in osteosarcoma U2OS cells. Pharmacol Rep 2017; 69 (5): 878-884.

21. Ramezani S, Vousooghi N, Ramezani Kapourchali F et al. Perifosine enhances bevacizumab-induced apoptosis and therapeutic efficacy by targeting PI3K/AKT pathway in a glioblastoma heterotopic model. Apoptosis 2017; 22 (8): 1025-1034.

22. Wang F, Ma H, Liu Z et al. $\alpha$-Mangostin inhibits DMBA/TPA-induced skin cancer through inhibiting inflammation and promoting autophagy and apoptosis by regulatingPI3K/Akt/mTOR signaling pathway in mice. Biomed Pharmacother 2017; 92: 672-680.

23. Ning H, Sun Z, Liu Y et al. Insulin Protects Hepatic Lipotoxicity by Regulating ER Stress through the PI3K/Akt/p53 Involved Pathway Independently of Autophagy Inhibition. Nutrients 2016; 8 (4): 227.

24. Qiu W, Leibowitz B, Zhang L et al. Growth factors protect intestinal stem cells from radiation-induced apoptosis by suppressing PUMA through the PI3K/AKT/p53 axis. Oncogene 2010; 29 (11): 1622-1632.

25. Zhang Y, Zhu C, Sun B et al. Integrated High Throughput Analysis Identifies GSK3 as a Crucial Determinant of p53-MediatedApoptosis in Lung Cancer Cells. Cell Physiol Biochem 2017; 42 (3): 1177-1191.

26. Zhang Y, Xia G, Zhang $Y$ et al. Palmitate induces VSMC apoptosis via toll like receptor (TLR)4/ROS/p53 pathway. Atherosclerosis 2017; 263: 74-81.

Received January 22, 2018. Accepted February 19, 2018. 